\title{
Evaluation of Health and Environmental Safety in Food and Water Production Factories in Duhok Governorate
}

\author{
Masood Abdulkareem Abdulrahman*, Kherailah Khodeda Bebo \\ Department of Public Health, College of Technical and Medical Techniques, Duhok Polytechnic University, Kurdistan Region- \\ Iraq,(masood.abdulkareem@dpu.edu.krd)(kherallahkhodeda@gmail.com) \\ *Correspondence: masood.abdulkareem@dpu.edu.krd
}

\begin{abstract}
Lack of adequate occupational safety and health strategies is a reason that workplace accidents in food and water production industries remain high, making this sector one of the riskiest operations worldwide. The research was carried out to examine the degree of implementing the health, occupational and environmental safety measures in the selected factories to assess health and safety level and to measurement the noise levels in these industries. A cross-sectional survey was conducted by utilizing structured pre-tested questionnaire and noise level measured at four places: selling, administrative, machine and passage industry places. The study revealed the absence of health and safety policy, and the absence of safety and training departments. The suitable measures in place to combat harmful dust generated by motor traffic were present in $23.3 \%$, and the system with deal with the spillage was current in $43.3 \%$ of factories. Wastes segregation was found in 3.3\%. Exhaust dilution ventilation system was seen in 83.3\% of these factories. Personal protection equipment was not provided to all workers exposed to dust, fumes, or gases. Only $3.3 \%$ of factory staffs were aware of fire prevention and safety measures. The sound level at the machine place was above average (above 85 decibels) in all factories.
\end{abstract}

Keywords: assessment, environmental safety, food factories, Duhok province

Received: July $16^{\text {th }}, 2021 /$ Accepted: Sept. $16^{\text {th }}, 2021 /$ Online: Sept. $27^{\text {th }}, 2021$

\section{INTRODUCTION}

Successful environmental health and safety programs usually receive strong support from senior management, which creates a supportive attitude throughout all levels of a factory. Thus, the first step in any program is the development and distribution of a policy statement, signed by a senior corporate executive officer, describing and supporting the initiation of a formal environmental health and safety auditing program. This policy statement sets the tone of the program (Cahill and Kane, 2010). Occupational risks impact employees and adversely affect factory behavior as it results in income loss and increasing labor costs (Leitão and Greiner, 2016). For business managers, acquiring safety and health skills is complex because accident prevention can be accomplished by adopting measures to minimize risk exposure (Chikono, 2017). Work-correlated diseases tend to be misjudged, so the incidence rates are typically calculated to compare industries. This implies that after the incidence of incidents at their worksites, food and water processing industries take preventive measures.

The imperfect Occupational safety and health (OSH) legislature in the Middle East countries has not been included in specific subdivisions' job rules or the OSH legislation. The

doi: 10.38094/jlbsr20244 majority of the labourers are unskilled, uninformed and unregistered. Moreover, there are no native directives, which are coupled with OSH (Hassan, 2012). The method of protection, wellbeing and environmental supervision is focused on the same validated management strategies used by factories to handle their other obligations, including manufacturing, operation, efficiency, expenditures and relationships with employees. Those establishments that manage their other responsibilities effectively will manage their protection, wellbeing, and environmental errands effectively if they use the same management procedures (Taylor, 2007). The conceptual model for identifying, diagnosing, treating, and managing illnesses, accidents, and other adverse health effects arising from hazardous environmental contamination in the workplace, home or community is job-related and ecological healthiness. Therefore, the identification, diagnosis, treatment, prevention, and management of illnesses, accidents, and other adverse health effects arising from hazardous environmental contamination in the workplace, home, or community is occupational and environmental health. It is part of public health - what we, as a society, do collectively to assure that the condition in which people live and work are healthy (Levy et al., 2011). Many people are now working in counterterrorism and 
responding to hazard attacks in programs run by the agencies indicated above and other agencies that have not been mentioned (Koren and Bisesi, 2016). Workers in the most hazardous sectors are at risk of injuries, illnesses, disability, and death (Rudolphi, 2017). Pollution of noise is attractive ever more and more severe in factories cities and the price of easing it in future years is expected to be insurmountable. The sources of annoying voice in Iraq are numerous, and that may be resulted from using the old vehicle or using enormous numbers of generators, or it may be caused by industrial machinery and processes such as electrical machinery and process such as drilling, carpentry, pneumatic tool, crushing, pumps and compressors, etc. (Yousif and Mahdi, 2013). The main study objectives were to assess the health and environmental safety levels in food and water production factories and measure noise levels.

\section{MATERIALS AND METHODS}

The study was carried out in the Duhok governorate, Kurdistan Region of Iraq, from $10^{\text {th }}$ May 2020 to $30^{\text {th }}$ July 2020. A cross-sectional study was conducted by using a pretested questionnaire. The questionnaire was divided into two parts: the first one requesting documents about health and safety such as (files, sheets, certificates, licenses and any hard copy evidence) to confirm the "yes" or "partial" or "no". This part included 62 questions, grouped in seven sections: (a) health and safety policy, (b) safety and health organization (safety department), (c) safety education and training (training and first aid), (d) general working condition (housekeeping, noise, ventilation and illumination), (e) waste disposal system, (f) personal protective equipment (PPE), and (g) fire protection. Possible answers were Yes/ Partial/ No. The last part was the measurement of sound level at industry places (direct selling, administration, machine and factory passage) and the SL Meter used in this study was a mini sound level detector (Model SL-MS-85). This mini-sound level detector is a digital meter for measuring the SL in decibels (dB). The cutoff point was $85 \mathrm{~dB}$.

According to the statistics of the Directorate of Preventive Health Affairs (DPHA, 2019), Sixty large factories which producing food-related products were registered, and $50 \%$ (30) of these factories were selected to be enrolled in this study through a proportionate random sampling table1 (DPHA, 2019).

Dairy products: Dairy products include a wide range of products includes liquid milk, fermented milk like yoghurt, labneh, cheese, butter, ghee, condensed milk, dry milk, cream, and whey product (FAO, 2021). Soft drink: any of a category of nonalcoholic beverages, typically but not limited to carbonated drinks, usually containing a natural or artificial sweetening agent, edible acids, natural or artificial flavors, and sometimes juice like fruit drinks, sports drinks, energy and vitamin drinks, sweetened iced tea, Pepsi, Coca-Cola, and lemonade (Suryakantha, 2014).
Table 1. Distribution of the selected factories according to their types.

\begin{tabular}{|l|c|c|}
\hline Factory type & $\begin{array}{c}\text { Registered Factories No. } \\
(\%)\end{array}$ & Selected factories \\
\hline Water & $10(16.7)$ & 5 \\
\hline dairy products & $12(20.0)$ & 7 \\
\hline soft drink & $9(15.0)$ & 4 \\
\hline Food & $29(48.3)$ & 14 \\
\hline Total & $60(100.0)$ & 30 \\
\hline
\end{tabular}

Food factories include other factories not listed in the above categories like chips, sesame, cake, doughnuts, cake, desserts, oil, canning. These factories are distributed among five districts of the Duhok Governorate (DG) (Duhok, Zakho, Sumel, Bardarash, and Amedi). Data collection analysis by SPSS version 25 was used for the statistical analysis (IBM Corp., Armonk, New York, USA). The data were subjected to descriptive statistical analysis. In addition, a pilot study was conducted on one factory in Duhok city center about two $\mathrm{Kms}$ and included 32 workers. It was performed to test the questionnaires and noise measurement. The questionnaire was validated by a panel of professionals who contributed some notes and changes. In addition, the researcher presented the questionnaire to 5 professionals specialized in community medicine and community health. The researcher and appropriate modifications considered their notes were made accordingly.

\section{RESULtS}

All of the selected factories neither had a health and safety policy nor a safety department. There is neither any training department nor facility in any factory nor any staff undergoes any training courses regarding safety rules. There is no ambulance or first aid unit and no competent or expert in first aid in all factories regarding first aid facilities. No previous studies upon environmental and safety were not conducted in any of the visited factories.

The halls, floors and stairways were found in good condition in $80 \%$ of factories, and $43.3 \%$ of them had a system to deal with the spillage. A clearly labelled enough disposable bins and suitably placed found only in $36.7 \%$. For dust, fume, and gas, most factories had enough regional dust, fume and gas evacuation and cleaning facilities. No inter-sectorial struggle for better housekeeping was noticed in all factories. Only $30 \%$ of factories had excellent housekeeping policies and procedures and made them acknowledged to the employees. A quarter $(26.7 \%)$ of them had working conditions that make the floors slippery, and $23.3 \%$ of the factories have adequate measures to combat harmful dust generated by motor traffic (Table 2).

The adequate natural ventilation and exhaust dilution ventilation system were present in $83.3 \%$ of factories. No any Personal Protective Equipment (PPE) given to workers exposed to dust, and fumes (Table 3 ).

At all factories, there were machines or processes that were generating noise, but the only factory had implemented control methods to reduce noise exposure below the 
permissible limits. None of the employees undergoes periodic audiometric tests (Table 4).

Table 2. Housekeeping conditions in selected factories

\begin{tabular}{|c|l|c|c|c|}
\hline \multicolumn{5}{|c|}{ Table 2. Housekeeping conditions in selected factories } \\
\hline Sn & \multicolumn{1}{|c|}{ Items } & $\begin{array}{c}\text { Yes } \\
\text { No. } \\
(\%)\end{array}$ & $\begin{array}{c}\text { Partial } \\
\text { No. } \\
(\%)\end{array}$ & $\begin{array}{c}\text { NO } \\
\text { No. } \\
(\%)\end{array}$ \\
\hline 1 & $\begin{array}{l}\text { Are all the corridors, floors and the } \\
\text { stairways in good condition? }\end{array}$ & $24(80)$ & $0(0.0)$ & $6(20)$ \\
\hline 2 & $\begin{array}{l}\text { Do you have the system to deal with } \\
\text { the spillage? }\end{array}$ & $13(43.3)$ & $0(0.0)$ & $17(56.7)$ \\
\hline 3 & $\begin{array}{l}\text { Do you have sufficient disposable bins } \\
\text { clearly marked and whether these are } \\
\text { suitably located? }\end{array}$ & $11(36.7)$ & $0(0.0)$ & $19(63.3)$ \\
\hline 4 & $\begin{array}{l}\text { Do you have adequate localized } \\
\text { extraction and scrubbing facilities for } \\
\text { dust, fumes and gases? }\end{array}$ & $29(96.7)$ & $0(0.0)$ & $1(3.3)$ \\
\hline 5 & $\begin{array}{l}\text { Are the walkways clearly marked and } \\
\text { free from obstruction? }\end{array}$ & $22(73.3)$ & $0(0.0)$ & $8(26.7)$ \\
\hline 6 & $\begin{array}{l}\text { Do you have any inter-departmental } \\
\text { competition form good housekeeping? }\end{array}$ & $0(0.0)$ & $0(0.0)$ & $30(100)$ \\
\hline 7 & $\begin{array}{l}\text { Has your organization elaborated good } \\
\text { housekeeping practices and standards } \\
\text { and made them known to the } \\
\text { employees? }\end{array}$ & $9(30)$ & $0(0.0)$ & $21(70)$ \\
\hline 8 & $\begin{array}{l}\text { Are there any working conditions } \\
\text { which make the floors slippery? }\end{array}$ & $8(26.7)$ & $0(0.0)$ & $22(73.3)$ \\
\hline 9 & $\begin{array}{l}\text { Does the factory have adequate } \\
\text { measures to suppress polluting dust } \\
\text { arising out from road transport? }\end{array}$ & $7(23.3)$ & $0(0.0)$ & $23(76.7)$ \\
\hline
\end{tabular}

Table 3. Ventilation in selected factories

\begin{tabular}{|c|c|c|c|c|}
\hline $\mathrm{Sn}$ & Items & $\begin{array}{l}\text { Yes } \\
\text { No. } \\
(\%)\end{array}$ & $\begin{array}{c}\text { Parti } \\
\text { al } \\
\text { No. } \\
(\%)\end{array}$ & $\begin{array}{l}\mathrm{NO} \\
\mathrm{No} . \\
(\%)\end{array}$ \\
\hline 1 & Is natural ventilation adequate or not? & $25(83.3)$ & $0(0.0)$ & $5(16.7)$ \\
\hline 2 & $\begin{array}{l}\text { Is there any exhaust dilution } \\
\text { ventilation system in any section of the } \\
\text { plant? }\end{array}$ & $25(83.3)$ & $0(0.0)$ & $5(16.7)$ \\
\hline 3 & $\begin{array}{l}\text { Are periodic / preventive maintenance } \\
\text { of the ventilation system carried out } \\
\text { and record maintained? }\end{array}$ & $12(40)$ & $0(0.0)$ & $18(60)$ \\
\hline 4 & $\begin{array}{l}\text { Does any ventilation system re- } \\
\text { circulate the exhausted air in work } \\
\text { areas? }\end{array}$ & $3(10)$ & $0(0.0)$ & $27(90)$ \\
\hline 5 & $\begin{array}{l}\text { Is personal protective equipment given } \\
\text { to workers exposed to dust, fumes and } \\
\text { gases? }\end{array}$ & $0(0.0)$ & $0(0.0)$ & $30(100)$ \\
\hline
\end{tabular}

The percentage of sound level at direct selling, administrative and passage factory places were average ( $85 \mathrm{~dB}$ or less), while at machine place, it was above average (above $85 \mathrm{~dB}$ ).

Table 4. Noise in the selected Industries

\begin{tabular}{|c|l|c|c|c|}
\hline Sn & \multicolumn{1}{|c|}{ Items } & $\begin{array}{c}\text { Yes } \\
\text { No. } \\
(\%)\end{array}$ & $\begin{array}{c}\text { Partial } \\
\text { No. } \\
(\%)\end{array}$ & $\begin{array}{l}\text { NO } \\
\text { No. } \\
(\%)\end{array}$ \\
\hline 1 & $\begin{array}{l}\text { Are there any machines/processes } \\
\text { generating noise? }\end{array}$ & $30(100)$ & $0(0.0)$ & $0(0.0)$ \\
\hline 2 & $\begin{array}{l}\text { Have engineering and administrative } \\
\text { controls been implemented to reduce } \\
\text { noise exposure below the permissible } \\
\text { limits? }\end{array}$ & $1(3.3)$ & $0(0.0)$ & $29(96.7)$ \\
\hline 3 & $\begin{array}{l}\text { Is there a system of subjecting all those } \\
\text { employees to periodic audiometric test } \\
\text { who work in high level noise areas? }\end{array}$ & $0(0.0)$ & $0(0.0)$ & $30(100)$ \\
\hline 4 & $\begin{array}{l}\text { Are the workers made aware of the ill- } \\
\text { effects of high noise? }\end{array}$ & $3(10)$ & $0(0.0)$ & $27(90)$ \\
\hline
\end{tabular}

\begin{tabular}{|c|l|c|c|c|}
\hline 5 & $\begin{array}{l}\text { Are any personal protective equipment } \\
\text { along with ear muffs/plugs provided and } \\
\text { used? }\end{array}$ & $1(3.3)$ & $0(0.0)$ & $29(96.7)$ \\
\hline
\end{tabular}

\section{DISCUSSION}

Top management should put mechanisms to define, document, and endorse an organization's official environmental health and safety (EHS) policy. The policy should explicitly define the organization's, faculty's, EHS personnel, and individual employees' duties and responsibilities. The intention should be stated in the EHS policy to: prevent accident, unfavourable, occupational exposures, and environmental events or alleviate both human and economic losses; incorporate environmental, health, and safety issues into all phases of operations, including laboratory discovery and development; attain and maintain legal and regulatory compliance and EHS performance should be improved on a regular basis. It should be disclosed to all employees and made readily available to relevant interested parties, as required (NRCRA, 2011). Unfortunately, none of the visited factories had any EHS policy.

For several years, education and preparation have been regarded as essential elements of coordinated safety initiatives. They are more critical than ever in the rapidly evolving high-tech workplace today. In ensuring that all staff at all levels undergo the required styles and quantities of instruction, modern safety and health practitioners play a crucial role (Goetsch, 2015).

The current study showed that each working shift has no first aid or ambulance room and no proficient trained first aid personnel. Employers must provide sufficiently equipment and facilities in domestic workplaces to enable their employees to get first aid if necessary (Day et al., 2003). Good housekeeping strategies including segregation of waste streams, inventory monitoring, control of staff, avoidance of spills and leaks, and improvement of scheduling. The redesign of goods or packaging decreases the material quantity or toxicity of the material and also helps to minimize the cost of electricity (Levy et al., 2011). Factory manufacturing procedures frequently generate a massive amount of particles; these particles often enter the air in occupied areas, posing a significant threat to the health of the workers (Hsu et al., 2012). According to Zhou et al (2007) about (113) factories in Shenzhen, China, have hazardous risks and (98) had excessive amounts of particulate matter. Over time, particulate matter exposure can lead to asthma, heart disease, laryngeal cancer, bronchial hyperresponsiveness, and lung cancer. Ventilation systems have a considerable impact on particle concentration in workplaces. Effective ventilation systems can lower airborne particle concentrations to tolerable levels while maintaining a suitable room temperature cancer (Chien et al., 2007).

PPE is a device that creates physical barriers between a worker and workplace risks in order to protect them from work-related injuries and diseases (Tamene et al., 2020) When engineering and administrative controls are neither 
practicable or effective in reducing these risks to acceptable levels, the goal is to reduce employee exposure to hazards. Wet floors, falling debris, and everything in between are examples of hazard threats. Protective helmets, eye protection, high-visibility clothing, safety footwear, safety harnesses, hearing protection, and, in some cases, respiratory protective equipment are all examples of PPE (OSHA, 2021). Despite the importance of actually having and using PPE by all employees in different organizations, the majority of the analysed industries did not provide their employees with the required PPE based on the factory worksite. Also, there is no unit of safety and employees consulted in the procurement of PPE, staff has not even been trained in the proper use of PPE, and only $10 \%$ of the working staff was provided with the necessary PPE. Employees may be at risk of a variety of accidents, illnesses, and disabilities. Wet floors, falling debris, and everything in between are examples of hazard threats. Protective helmets, eye protection, high-visibility clothing, safety footwear, safety harnesses, hearing protection, and, in some cases, respiratory protective equipment are all examples of PPE (OSHA, 2021).

Dilution ventilation supplies and exhausts large amounts of air to and from an area or building. It usually involves large exhaust fans placed in the walls or roof of a building. Dilution ventilation controls pollutants generated at a worksite by ventilating the entire workplace (CCOHS, 2021). This study revealed that most of the factories had exhaust dilution ventilation systems, but they did not undergo periodic maintenance in most factories. The vast majority of factories had not recirculated ventilation system which usually provided dust reduction without increasing concentrations of hazardous gases (Anthony et al., 2015). When engineering and administrative controls are neither practicable or effective in reducing these risks to acceptable levels, the goal is to reduce employee exposure to hazards.

High levels of occupational noise, which can cause health problems, are widespread in various industrial activities. The intensity of the impacts is dependent not only on the power but also on the type of effect. Exposure time, frequency, and noise type. According to World Health Organization (WHO) high levels of noise will interfere with speech. They can cause a decrease in productivity, excessive blood pressure, hearing loss and other health issues like interference with sleep, cardiovascular diseases, loss of appetite and tiredness (Ibrahim, 2014).

Noise pollution is a global occupational health concern with significant social and physiological consequences. Loud noise exposure from all sources contributes to roughly $20 \%$ of adult-onset hearing loss, with occupational noise accounting for $16 \%$ of debilitating hearing loss in adults. Noise-induced hearing loss is ranked as the world's 15 th most crucial health problem (Deborah, 2005). Noise pollution is rampant in industrial plants in the Duhok Region factories have noise pollution above $85 \mathrm{~dB}$. Most staff, managers, and factory owners are unaware of the noise problem. No protection protocols or shields, or procedures are in place to protect noisy machines and equipment from threat. Even though the laws are in effect in Iraq (The Rules of the Environment). But the statutory activation is incomplete or ignored or completely unknown. Therefore, the media should play a particular role in this issue (Yousif and Mahdi, 2013). A survey of 90 workers from various businesses in Duhok indicated that noise levels in all industries are much higher than the maximum (OSHA) exposure restrictions. Noise in the workplace irritates $81.11 \%$ of workers, and $65.56 \%$ of respondents in these industries have hearing issues, $34.44 \%$ have complaints about ringing in the ears, and only $10 \%$ of workers were used PPE (Al-Dosky, 2014).

\section{V.CONCLUSIONS}

This study showed that all selected factories had neither a health and safety policy nor a safety department. There is neither any training department nor facility in any factory or did any staff undergo training courses regarding safety rules. There is no ambulance or first aid unit. The majority of factories had enough dust, fume, and gas evacuation and cleaning facilities. Only one-third of factories had good housekeeping policies and procedures, and made them acknowledged to the employees. The vast majority of factories had adequate natural ventilation and an exhaust dilution ventilation system. No PPE was given to workers exposed to dust and fumes. Each country should develop $\mathrm{OSH}$; a comprehensive countrywide program focused on accident prevention that happens while working. The strategy would decrease the outlays associated with workplace mishaps and improve productivity by reducing the sources of critical hazards in workplaces. The factories need to build a safety department suitable for the size and strength of the environmental safety and health department. It demands enough people to perform their jobs effectively, while too many people would be an additional burden on the industry. The usage of PPE should be made mandatory.

\section{The authors declare no conflict of interest}

\section{REFERENCES}

Al-Dosky, B.H.A. (2014). Noise level and annoyance of Industrial factories in Duhok city. IOSR- Journal of Environmental Science, Toxicology and Food Technology, 2014,8(5), 1-8.

Anthony, T.R., Altmaier, R., Jones, S., Gassman, R., Park, J.H., Peters, T.M. (2015). Use of Recirculating Ventilation with Dust Filtration to Improve Wintertime Air Quality in a Swine Farrowing Room. Journal of Occupational and Environmental Hygiene, 12(9), 635-46.

Cahill, L. B., Kane, R. W. (2010). Environmental health and safety audits. Government Institutes.

Chien, C.L., Tsai, C.J., Ku, K.W., Li, S. N. (2007). Ventilation Control of Air Pollutant during Preventive Maintenance of a Metal Etcher in Semiconductor Industry. Aerosol and Air Quality Research,7(4), 469488.

Chikono, N.N. (2017). Leadership Practices That Improve the Workplace Safety Environment.Ph D thesis, Walden University, College of Management and Technology, Minneapolis, USA. Retrived May 15, 2021, from https:// scholarworks.waldenu.edu/ cgi/ viewcontent.cgi? article $=4538$ and context $=$ dissertations. 
CCOHS. (2021). OSH Answers Fact Sheets, Canadian center for occupational Health and safety. Retrieved August 21, 2021 from https://www.ccohs.ca/ osh answers / prevention/ ventilation/ introduction.html.

Day, R., Rowland, E., Reader, J.A. (2003). Health Safety and Environment Legislation. A Pocket Guide. First edition :Royal Society of Chemistry.

Deborah, I.N. Robert, Y.N., Marisol C.B., Marilyn F. (2005). The global burden of occupational noise-induced hearing loss. American Journal of Industrial Medicine, 48(6), 446-458.

DPHA. (2019). Directorate of Preventive Health Affairs in Duhok Governorate. Annual Statistics.

FAO. (2021). Food and Agriculture Organization of the United Nations. Retrived February 28, 2021, from http://www.fao.org/dairyproduction-products/products/ types-and-characteristics /en/.

Goetsch, D.L. (2015). Occupational safety and health for technologists, engineers, and managers. Eighth edition: Pearson.

Hassan, S.A. (2012). Health, safety and environmental practices in the construction sector of Pakistan. Master thesis, Uppsala University, Sweden. Retrived May 25, 2021, ftom http://www.divaportal.org/smash/ get/diva2: 562426 / FULLTEXT01.pdf.

Hsu, H.I., Chen, M.R., Wang, S.M., Chen, W.Y., Wang, Y.F., Young, L. H., Huang, Y.S., Yoon, C.S. Tsai, P.J. (2012). Assessing Long-Term Oil Mist Exposures for Workers in a Fastener Manufacturing Industry Using the Bayesian Decision Analysis Technique. Aerosol and Air Quality Research, 12(5), 834-842.

Ibrahim, I.B., Aremu, A.S., Ajao, K.R., Ojelab, A.T. (2014). Evaluation of Noise Pollution and Effects on Workers during Wheat Processing.Journal of Applied Sciences and Environmental Management, 18, (4), 599-601.

Koren, H., Bisesi, M. (2016). Handbook of Environmental Health, Volume II: Pollutant Interactions in Air, Water, and Soil. Fourth edition: CRC press.

Leitão, S., Greiner, B.A. (2016). Organizational safety climate and occupational accidents and injuries: an epidemiology-based systematic review. Work stress, 30(1), 71-90.

Levy, B.S., Wegman, D.H., Baron, S.L., Sokas, R. K. (2011). Occupational and Environmental Health: Recognizing and Preventing Disease and Injury.Sixth edition: Oxford University Press.

NRCRA. National Research Council of the Research Academies. (2011).Prudent Practices in the Laboratory: Handling and Management of Chemical Hazards. Updated version:The national Acedemic Press. Retrived May 5, 2021, from https://www.ncbi. nlm. nih. gov/books/NBK55873/\#ch2.s9.

OSHA. (2021). Personal protection equipment. Occupational Safety and Health Administration.Retrived April 22, 2021 from https:// www. osha.gov/personal-protective-equipment.

Rudolphi, J.M. (2017). Occupational safety and health of young adult agricultural workers. PhD thesis Graduate College, The University of Iowa,USA.Retrieved May 29,2021, from https://ir.uiowa.edu/etd/5617/.

Suryakantha, A. (2014). Community Medicine With Recent Advances.Third edition: Jaypee Brothers,Medical Publishers Pvt. Ltd.

Tamene, A., Afework, A., Mebratu, L. (2020). A Qualitative Study of Barriers to Personal Protective Equipment Use among Laundry Workers in Government Hospitals, Hawassa, Ethiopia. Journal of Environmental and Public Health, 1-14.

Taylor, B.(2007). Effective environmental, health, and safety management using the team approach. First Edition: Kindle Edition: Wiley-Inter science.

Yousif, K.M., Mahdi, B.H. (2013) . Effects of Occupational Noise Exposure on Arterial Blood Pressure of Workers in Selected Industrial Places in Duhok City. Science Journal of University of Zakho, 1(1), 308-318.

Zhou, J., Jiang, L.X., Zhang, X.J. (2007). Determination of the poisonous and hazardous factors in the worksites of the enterprises of Futian District. Occupational Health, 4: 256-257. 